Neurociências

\title{
Fisiologia do exercício
}

\section{Physiology of Exercise}

\section{Antonio Carlos da Silva}

Escola Paulista de Medicina / Universidade Federal de São Paulo - UNIFESP.

Durante atividade física diferentes mecanismos de suporte energético para o trabalho muscular são mobilizados. Dependendo do tipo, intensidade e duração do exercício o metabolismo predominante será anaeróbio alactico, láctico ou aeróbio.

$\mathrm{O}$ conhecimento das respostas fisiológicas normais ao exercício permite a identificação de padrões alterados pelas doenças e conseqüentemente o uso clínico do exercício físico. Existem particularidades nas respostas fisiológicas ao exercício nas doenças neuromusculares. Por exemplo, a redução da massa muscular ativa ou um déficit enzimático especifico podem alterar respectivamente o comportamento das variáveis cardiorrespiratórias e metabólicas (ácido láctico por exemplo) durante o exercício. 